\title{
Technical Vocational Education: As a Veritable Tool for Eradicating Youth Unemployment.
}

\author{
${ }^{1}$ Audu, Rufai, ${ }^{2}$ Yusri Bin Kamin, ${ }^{3}$ Farhad Balash \\ ${ }^{1,2}$ Department of Technical \& Engineering Education, Universiti of Teknologi Malaysia, \\ ${ }^{3}$ Department of Educational Development, Universiti of Teknologi Malaysia
}

\begin{abstract}
The level ofyouth unemployment in Nigeriaisvery high in Nigeria; with itsattendantadverse psychological, social, occupational and financial effects. This paper stresses on thecauses and consequences of youth unemployment in Nigeria. The paper also highlights on Technical Vocational Education (TVE) in Nigeria. Conclusions were drawn and recommendations made on how TVE will reduce the level of youth unemployment in Nigeria amongst which are: Graduates of the programs should be encouraged to be selfemployed by assisting them with soft loans and/or micro credit. The quality of technical and vocational educational output must be improved if the expected outcome of employment creation and poverty reduction is to be achieved. The task of TVE provision cannot be tackled by government alone. The involvement of major Nigerian stakeholders, complemented by partnerships with international agencies, NGOs, Foundations, (etc.) will be essential if the goals and potentials of Nigerians are to be realized using TVE for job creation and poverty alleviation.
\end{abstract}

Keywords: Technical Vocational Education, Unemployment, Youth Unemployment, Nigeria

\section{Introduction}

Nigeria is the most populated country in Africa and the eight in the world with a population of over 140 million people (National Population Commission, 2006). Nigeria is the eighth largest oil producing country in the world, but it has the largest population of poor and unemployed people in sub-Saharan Africa and is ranked $158^{\text {th }}$ on the human development index. There is general high-income inequality, which has perpetuated the concentration of wealth of the nation in the hands of a few individuals(ActionAid Nigeria, 2009). With a nominal GDP of \$207.11 billion and per capita income of \$1,401 it has the second largest economy in Africa. As remarkable as the above figures may seem youth unemployment has been one of the major problems facing the country. A high level of unemployment and underemployment is one of the critical socio-economic problems facing Nigeria(Salami, 2011). While the labor force grows, with an increasing proportion of youth, employment growth is insufficient to absorb labor market entrants. As a result, youth are specifically affected by unemployment. Moreover, youths are more likely to be employed in jobs of low quality, underemployed, working long hours for low wages, engaged in dangerous work or receive only short term and/or informal employment arrangements. The inadequate employment situation of youth has a number of socio-economic, political and moral consequences. This has given rise to high level of poverty in Nigeria. The share of the total population living below the $\$ 1$ a day on the threshold of 46 per cent is higher today than in the 1980s and 1990s, despite significant improvements in the growth of GDP in recent years. (Aiyedogbon \& Ohwofasa, 2012)

In most developing countries like Nigeria, governments and policy makers are increasingly finding it difficult to deal successfully with the problem of youth unemployment. This high level of unemployment can be attributed to lack of adequate provision for job creation in the development plans, the ever expanding educational growth and the desperate desire on the part of youths to acquire university education irrespective of course and course contents. As a result, a number of skills acquired from the university appear dysfunctional and irrelevant (Okafor, 2011). In Nigeria, the federal government in 2008 acknowledged the fact that about 80 per cent of Nigeria's youth are unemployed and 10 per cent underemployed(Daily Times, 2008). In 2011, the Minister of Youth Development, Bolaji Abdullahi reported that 42.2 per cent of Nigeria's youth population is out of job. Depo Oyedokun, the Chairman of the House Committee on Youth and Social Development revealed that of the over 40 million unemployed youths in the country, 23 million are unemployable and therefore susceptible to crime, hence the need to articulate what could be done to salvage the situation (Emeh, Nwanguma, \& Abaroh, 2012). The rate of unemployment is increasing because most graduates lack relevant marketable skills that will make them employable in industries or related organizations as a result of this there is high level of unemployment in Nigeria. 


\section{Technical Vocational Education Defined}

Technical and Vocational Education (TVE) is that aspect of education that exposes the learner to acquisition of demonstrable skills that could be transformed into economic benefits (Akerele, 2007). According to Dike(2009)TVE is that aspect of education which leads to the acquisition of skills as well as basic scientific knowledge. It is a planned program of courses and learning experiences that begins with exploration of career options, supports basic academic and life skills, and enables achievement of high academic standards, leadership, preparation for industry-defined work, and advanced and continuing education(Maclean \& Wilson, 2009). The Federal Republic of Nigeria (FRN) in the National Policy on Education(FRN, 2004)sees TVE as a comprehensive term referring to those aspects of the educational process involving, in addition to general education, the study of technologies and related sciences and the acquisition of practical skills, attitudes, understanding and knowledge relating to occupations in various sectors of economic and social life'. Technical education can therefore be seen as the formal training of persons to become technicians in different occupations. Thus any education that is geared towards teaching technical skills and attitudes suitable to such skills can be regarded as technical education.

The primary objective of all TVE programs is the acquisition of skills and attitudes for gainful employment in a specific occupation or professional area. The need to link training in TVE to employment either self or paid employment is at the base of all the best practices and approaches observed throughout the world. One of the most significant aspects of TVE is its inclination towards the world of work and the emphasis of the curriculum on the acquisition of employable skills. TVE delivery systems are therefore; well placed to train the skilled workforces that the nation needs create employment for the youths and emerge out of poverty.

\section{Concept of Unemployment}

Unemployment is a very complex phenomenon. It is quite very simple to notice but hard to define. Generally, unemployment may imply lack of employment. Thus, anyone who is able to work and above certain agelimitand is unoccupied may be considered as being unemployed for that period. Normally, the term unemployment implies a condition of joblessness. Unemployment refers to aphenomenon where people who are willing and capable of working are unable to find suitable paid work Fajana (Emeh, eta'l., 2012).

The concept unemployment has been defined as a condition in which people who are willing to work at the normal wage rate are unable to find jobs. It is one of the problems which every responsible government is expected to check and regulate. The higher the unemployment level in an economy the higher would be the poverty level and associated welfare challenges. Unemployment is one of the developmental problems that face most developing economy in the 21st century (Patterson, eta'l., 2006). Nigeria is not exempted from this phenomenon. In recent times, the definition of unemployment is said to be more encompassing, the unemployed is a member of the economically energetic population, who are without work but available and seeking for work, including people who have lost their jobs and those who have willingly left work World Bank (Akintoye, 2008).

Unemployment is a global trend, but occurs mostly in developing countries of the world, with attendant social, economic, political, and psychological implications. Therefore, massive youth unemployment in any country is a signal of far more complicated problems (Okafor, 2011). Unemployment in Nigeria can be classifiedinto two categories: the older unemployed who lost their jobs as a result of retrenchment, redundancy or bankruptcy; and the younger unemployed, most of who have never being employed(Oyebade, 2003).

Youth unemployment, could be termed as numerous youths from diverse background, willing and able to work, but cannot find any. When the supply of labor surpasses the demand for labor, it results to joblessness and unemployment. Given the lack of sufficient employment opportunities in the formal sector, youths may be forced to engage in casual work and other unorthodox sources of livelihood, thus leading to underemployment Echebiri, (2005); Gibb \& George (Emeh, eta'l., 2012).

\section{Youth Unemployment Situation in Nigeria}

In Nigeria, data on the accurate rateof unemployment is difficult to access. However, according Awogbenle \& Iwuamadi (2010)the statistics from the Manpower Board and the Federal Bureau of Statistics indicated that Nigeria has a youth population of 80 million, representing $60 \%$ of the total population of the country. Also, 64 million of the youths are unemployed, while 1.6 million are under-employed. The 1990-2000 data on youth unemployment revealed that the largest group of the unemployed is the secondary school graduates. Also, $40 \%$ of the unemployment rate is among urban youth aged $20-24$ and $31 \%$ of the rate is among those aged 15-19. Also, two third (2/3) of the urban unemployed are ranged from 15-24 years old. Moreover, the educated unemployed tended to be young males with few dependents. There are relatively few secondary school graduates and the lowered job expectations of primary-school graduates. However, there is no consistent trend of unemployment rates in Nigeria. A rise in one or two years is sometimes followed by a drop in the subsequent years. .According to National Bureau of Statistics (NBS, 2009:238; 2010:2 2012), the national 
unemployment rates for Nigeria between 2000 and 2011 showed that the number of unemployed persons constituted $31.1 \%$ in $2000 ; 13.6 \%$ in $2001 ; 12.6 \%$ in $2002 ; 14.8 \%$ in $2003 ; 13.4 \%$ in $2004 ; 11.9 \%$ in 2005 ; $13.7 \%$ in $2006 ; 14.6 \%$ in $2007 ; 14.9 \%$ in $2008 ; 19.7 \% 2009 ; 21.1 \%$ in 2010 and $23.9 \%$ in 2011 ; and is projected to hit 25\% at the end of 2012 (United State Embassy in Nigeria, 2012). Figure 1. shows the rate of unemployment from 2000 - 2011 in Nigeria.

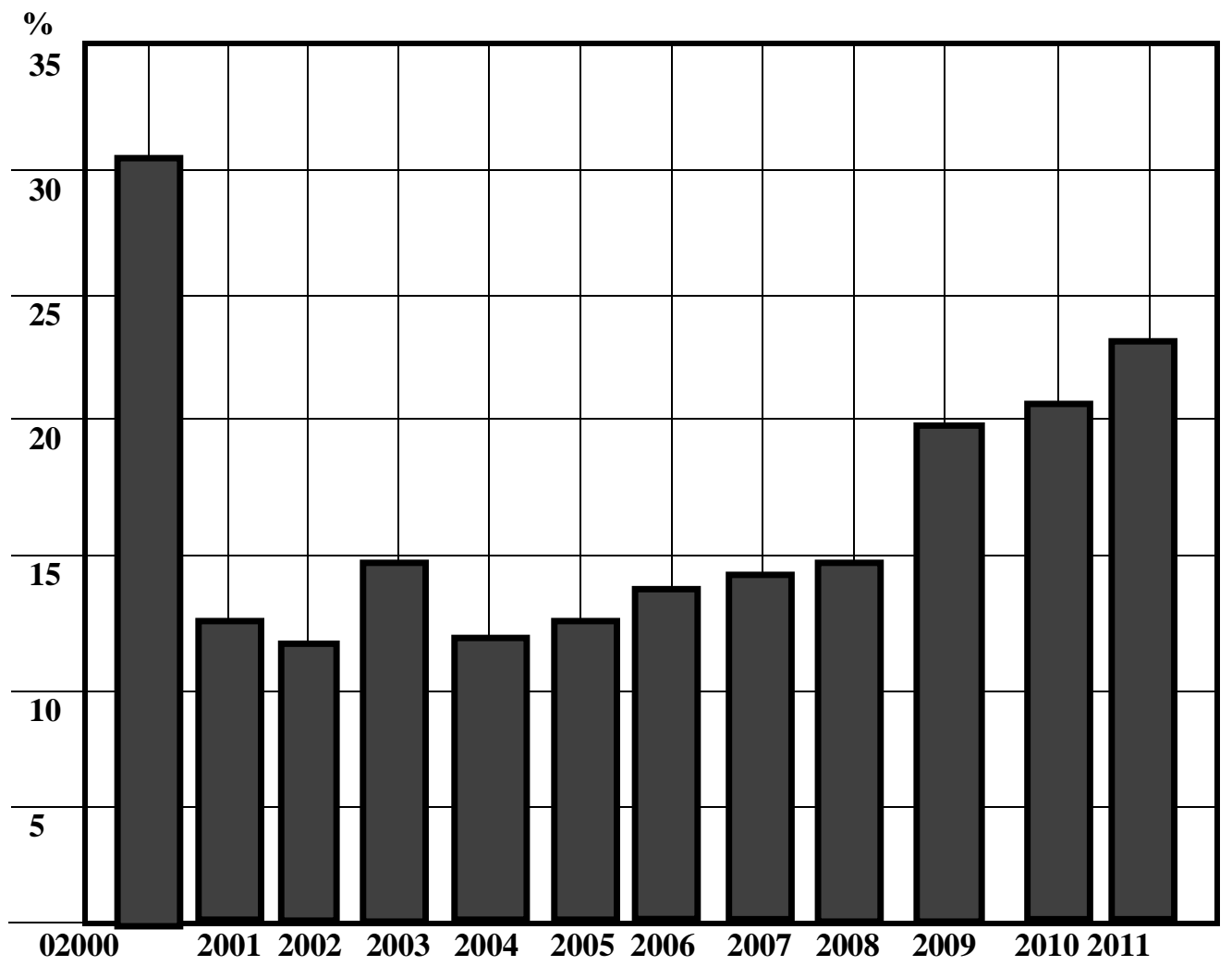

Figure 1: Rate of Unemployment in Nigeria

Source: (NBS, 2012)

Therefore, with regards to the age group, educational group and sex, data provided by the National Bureau of Statistics (NBS, 2010:3) further revealedthat as at March 2009 in Nigeria, for persons between ages 15 and 24 years, $41.6 \%$ were unemployed. For persons between 25 and 44 years, $17 \%$ were unemployed. Also, those with primary education, $14.8 \%$ were unemployed and for those with only secondary education, $23.8 \%$ were unemployed. Furthermore, for those with post-secondary education, $21.3 \%$ were unemployed. For those who never attended school and those with below primary education, $21.0 \%$ and $22.3 \%$ were unemployed respectively. With regards to sex, data presented indicated that males constituted $17.0 \%$ while females constituted $23.3 \%$.

However, it is important to note that the figures above may not have captured in totality the youth unemployment situation in Nigeria, however, they are pointing to the fact that the phenomenon is a very serious issue with far-reaching consequences to the nation.

\section{Causes of Unemployment in Nigeria}

Youth unemployment has been skyrocketing in Nigeria the principal causes of youth unemployment havebeen classifiedby several scholars (Alanana, 2003;Echebiri, 2005;Ayinde, 2008;Awogbenle \& Iwuamadi, 2010;Anyadike, Emeh, \& Ukah, 2012). The increase in population is one of the causes of unemployment in Nigeria (140,431,790 as per 2006 census) and is projected to be over 180 million by 2020 if the annual growth rate of 3.2\% continues National Population Commission (NPC, 2009). While the population increases, the number of industries growth is dwindling and if nothing serious is done, both population and unemployment will continue to rise.

The youths lack the relevant skills required by employers' as well as for self-employment. The curriculum in our TVE institutions is said to be obsolete and the graduates of such institutions are deficient in terms of employability skills. Some scholars and commentators have maintained that as far as the formal sector 
is concerned, the average Nigeria graduate is not employable and, therefore, does not possess the skills required by the employers of labor for a formal employment. Often, this is attributed to the Nigeria's education system, with its liberal bias. The course contents of most educational institutions in Nigeria lack contents that would enable graduates to acquire technical as well as entrepreneurial skills to become job creators rather than job seekers (Okafor, 2011).

The cause of youth unemployment is also as a result of public negative attitude towards TVE as education for the low status (Nwokomah, 2005). This stems from the low image of 'blue-collar' jobs which TVE offers. Before and after independence, the Nigerian education system prepared students for basic "white collar' jobs. Over time, the paucity of jobs led to high unemployment rate and also a high level of poverty in the society (Moja, 2000;Ebong \& Leigha, 2006). The Nigerian societywrongly believes that those who are not academically inclined study TVE subjects. It is because of this reason that most parents are not willing to encourage their wards to study TVE subjects. The fact remains that most parents are apt to want an academic education for their children, whether or not graduates increasingly finds it difficult to get jobs or not. They do not want their children to go to schools for the purpose of becoming bricklayers, carpenters, mechanics (Nwokomah, 2005). The urge for certificates and degrees in preference to technical vocational skills stems from the fact that when it comes to political appointments, leadership positions and decision making, graduates with degree certificates in different fields are favored most than their counterparts with technical vocational skills.

Furthermore, the rapid growth of the educational system has led to the risein the supply of educated manpower above the corresponding demand for them. This contributes to the problem of the youth unemployment in Nigeria. For instance, according to Manning \& Junankar (Okafor, 2011) the total number of graduates turned out by the higher institutions in Nigeria, which were 73,339 in 1986/1987 which rose to 131,016 in 1996/1997. Presently, with over 97 universities in Nigeria (both federal, state, and private) and the increasing demand for higher education there has been the problem of suitable employment for the numerous graduates that are turned out by these higher institutions annually. Ordinarily, this should not have been a problem, but the fact isthat the Nigerian economy is too feeble to absorb this large number of graduates(Utomi, 2011).

\section{Consequences of Unemployment}

Unemployment of youths has several implications; it has adverse psychological, social, occupational and financial consequences on them Fajana(Shadare \& Tunde, 2012). Unemployment has serious impacts both on their present living conditions and their attitude in the future and on the society in which they are supposed to be part. Youth unemployment literally devastates them morally and raptures the ties and relationship they form. People who have no jobs feel irrelevant and inferior. And always having the feeling that they are rejected from the rest of the society, with these feelings the youths can resort to criminal activities and violence.

Bennel(Ajaegbu, 2012) argued that urban society is becoming progressively criminalized, especially with the proliferation of youth gangs. Neither homes, nor markets are safe in Nigeria because of repeated occurrence of armed robbery incidents. Unemployment problem, which now seems beyond remedy, has produced mass of idle hands and some of them have decided to punish the society that fails to provide them with means of livelihood and dignity by robbing its members of their properties at gunpoint (Ideyi, 2010). The police cannot perform successfully because they are overstressed by the amount of cases that awaits them daily, and the situation is worsened by obsolete instruments they use that are no match to the modern sophisticated weapons used by the criminals.

Unemployment have alsomultipliedthe number of aggrieved youths and resulted in the emergence of area boys' andAlmajiriswho target the very society that alienated them(Ibrahim, 2006). In a survey conducted on the socioeconomic characteristics of the armed militant groups in Nigeria namely Bakassi Boys, $\mathrm{O}^{\prime}$ odua People's Congress (OPC) and Egbesu Boys were made up of youths within $16-17$ years (40\%), 18 - 19 years (10\%), $20-21$ years $(20 \%)$, and $20-23$ years $(20 \%)$. Approximately $60 \%$ of them were unemployed (Awogbenle \& Iwuamadi, 2010).

The unemployed youths, have been used as local militants to attack, bomb, vandalize and destroy oil pipelines, lives and property in the Niger Delta region of(Gilbert, 2010;Ojakorotu, 2010). For more than a decade, this group of youths have formed the larger population of the militants in the areas who have been terrorizing and kidnapping both the expatriate and local oil workers and demanding large amount as ransoms(Epelle, 2010). The most recent kidnap case was the kidnap of mother of the coordinating minister of economy/finance minister Dr Ngozi Okonjo- Iweala(Nwabuikwu, 2012). With all these kinds of kidnapping including those of the political opponents or their relatives and expatriatestaking place in parts of Nigeria thereby, creating a general state of insecurity. It is pertinent to note that no responsible or sane investor would want to invest in a country characterized by insecurity, confusion and uncertainty. Besides the reluctance of new investors to come in to invest in insecure and unstable environment, the existing investors may wish to relocate 
their investments to safe place. All these on the run long will worsenthe crisis of youth unemployment and further reduce the economic fortunes of Nigeria.

Unemployed youths have been used to spreadethno-religious clashes in Nigeria (Ibrahim, 2006;Okafor, 2007). However, the utilizationand exploitationof mostly unemployed and ignorant youths to perpetuate post elections violence during 2011 presidential election declared to be free, fair, transparent and credible by both local and international observers thatclaimed over five hundred lives in states like Kaduna, Kano, Bauchi, Katsina and Gombe (including overnine youth corps members on national assignment) and displaced over fifteen thousand people in the Northern partsof Nigeria is a clearsign of an attempt to use this group of youths to perpetuate crime and violence in the nation (Adepegba, 2011;Ibrahim, 2011;Lartey, 2011;Olatunji \& Abioye, 2011).

In addition, there has been upsurge in the involvement of youths in various anti-social activities and crimes as a result of unemployment. Such crimes include; arson, assault, murder, abduction, stealing, armed robbery, prostitution and sexoffences, unlawful possession of arms and so on. Figures supplied by the Nigerian Prisons Service (National Bureau of Statistics, 2009:248) actually confirmed this. For instance, persons admitted into the prisons by age group between 2004 and 2008 showed that as regards the youths between the ages 16 and 20 years, 31,700 youths were admitted in 2004. Others include; 40170 youths (in 2005); 19, 122 (in 2006); 16,236 (in 2007); and 25, 317 (in 2008). As regards the youths between ages 21 and 25 years, 39,045 youth were admitted in 2004; 34, 600 (in 2005); 28705 (in 2006); 57,736 (in 2007) and 28, 049 (in 2008). Also, for persons between ages 25 and 50 years, 63,100 persons were admitted in 2004; 65, 140 (in 2005); 75,491 (in 2006); 80, 134 (in 2007) and 73, 071 (in 2008). All these figuresshow that in Nigeriaagreat of number youths are into anti-social and criminal activities mainly as a result of unemployment.

\section{Technical Vocational Education in Nigeria}

Nigeria as a nation currently has many social and economic problems to handle in the twenty-first $\left(21^{\text {st }}\right)$ century. Most Nigerians are just recovering from continuing case of negative attitude towards TVE. Nigeria is similarly just awakening from her long sleep of neglect of these aspects of education in her educational system Mbanefoh\& Bamiro(Apagu \& Andural, 2007). The nation and her citizens are in the twentyfirst century questioning the quantity and quality of these aspects of education in the nations system of education and among Nigerians, particularlyamong the youths.

A brief look at the National Policy on Education (NPE) aims of TVE amongst others shows the rationale for government interestand support to the skill-oriented education. In addition to TVE providing skilled manpower and reducing youth unemployment, it has contributed significantly to economic development by reducing poverty through access to various income areas, supporting foreign investment and largely transforming attitudes of people to TVE (Adebambo, 2007). Prior and after independence, the system of TVE in Nigeria was the continuation of the colonial system. Much of what goes into TVE was modelled after the apprenticeship system. TVE was first brought into the mainstream of Nigerian education through the creation of the Yaba Higher College in 1932 and some other trade centers. After independence, the number of technical schools and student enrolmentimproved.Unfortunately, it was not followed by the provision of facilities for workshop practice. At this time, TVE was established based on making a balance between manpower requirements for supplying industrial expansion and educational aspiration of the Nigerian nation. Review of the recommendation of the Ashby commission of 1960 discloses that TVE was further relegated by putting it below university education, awarding city and guilds certificate as oppose to university certificate and by not providing training for TVE teachers (Onyene, eta'l., 2007).

Adebambo (2007) noted that in the previous, the effort to promote TVE has ignored the provision of trained teachers. He recalled that the National Teachers Training Certification was needed to meet the demand for technical teachers in many technical institutions and training schools. The emphasis then was on how to teach and what not to teach. This led to the establishment of the Nigerian Certificate in Education (Technical) program. This has more content on what to teach and a little about how to teach. Also, in the past, technical teachers were sent overseas for training because of the cost implication it was stopped. In recent times, they are trained through the Technical Teachers Training Program (TTTP) the resultant effect has been a shortage of teaching personnel in the technical schools. To compound the problem, the NPE just like the Ashby commission recommendation ignored the issue of production of teachers for TVE.Awakuna(2006)affirms that the problem of production of TVE teachers has resulted in their paucity which is one of the obstacles in TVE in Nigeria.

It was also noted by Aina (Agbolade, 2007)that government neglect in terms of inadequate funding of the training program has not helped the TVE teachers hence their insufficiency in the technical colleges. Whilst the problem of shortage of technical teachers exists in the country generally, a study carried out in one of the Federal Colleges of Education (Technical) by Onyene eta'l., (2007) revealed that the teachers are qualified but fairly adequate in the quantityneeded. Another study by Kalejaye (2007)revealed that present day technical teachers are good in theory but lacking in practice. In the same vain, Ashaye(2007)countered this in his own 
study which revealed that technical teachers have practical knowledge but are hindered by lack of appropriate instructional resources.

TVE in Nigeria has encountered a lot of problems during its developmental stage. Amongst these is the problem of insufficient provision of instructional materials, tools and equipment. Experts in the field of TVE have expressed the necessity for adequate physical, human and financial resources to effectively execute a TVE based curriculum. Akaninwor (2001)in his study traced the technological backwardness in the country to lack of infrastructure and equipment for TVE. Puyate (2001)is of the view that instructional facilities should be looked at vis-à-vis the curriculum in order to make TVE effective. He stressed ona TVE curriculum that will meet the present needs of the $21^{\text {st }}$ century demands of the society. Supporting his view, Aghenta (Onyene, eta'l., 2007) affirms that the TVE curriculum should be based on occupational and manpower needs to avoid irrelevant courses and time wastage.

Another problem of TVE in Nigeria is that it is seen by the society as education for the low status (Nwokomah, 2005). This is as a result of the low image of 'blue-collar' jobs which TVE offers. The Nigerian education system before independent and even after independence prepared students for basic "white collar' jobs. Over time, the paucity of jobs led to high unemployment rate and also a high level of poverty in the society (Moja, 2000; Ebong \& Leigha, 2006). The Nigerian society wrongly believes that those who are not academically biased study TVE subjects. It is because of this reason that most parents are not willing to encourage their wards to study TVE subjects. The urge for certificates and degrees in preference to technical vocational skills is as a result of the fact that when it comes to political appointments, leadership positions and decision making, degree holders in different fields are favored most than their counterparts with technical vocational skills (Nwokomah, 2005).

\section{Conclusion}

There is a high level of youth unemployment in Nigeria according to research findings and statistical data, despite the initiatives of the government in coming up with several programs to reduce the level of youth unemployment which has failed to yield the desired result. In order to eradicate or reduce the level of unemployment in Nigeria greater emphasis must be placed on TVE. No meaningful youth employment program can be achieved without efficient and effective TVE program. The promotion of TVE program will lead to wealth creation, employment generation and sustainable livelihood.

\section{Recommendations}

The following recommendations are made in order to mitigate or reduce the level youth unemployment in Nigeria through TVE:

- The task of TVE provision cannot be tackled by government alone. The involvement of major Nigerian stakeholders, complemented by partnerships with international agencies, NGOs, Foundations, (etc.) will be essential if the goals and potentials of Nigerians are to be realized using TVE for job and employment creation

- There should be linkage between TVE institutions and industries by using some of the experienced supervisors as teachers. The industry based training should be financed and organized and delivered by public entities which is a private sector driven. The government should only come in when it comes to regulatory aspect of the training, for example to check the indiscriminate acts of some TVE providers.

- The society needs re-orientation in order to change their wrong perception about TVE. In advanced nations individuals with technical skills and experience in relevant fields are highly respected and thus work in tandem with those with formal education. The worth of every worker should depend on the person's skills and knowledge and not the stack of academic degrees one has

- Graduates of the programs should be encouraged to be self-employed by assisting them with soft loans and/or micro credit. The quality of technical and vocational educational output must be improved if the expected outcome of employment creation and poverty reduction is to be achieved.

- The government should come out with a clear-cut policy on what is the role of TVE institutions in terms of human capital development for employment creation

- The government should provide power and other infrastructural facilities so as to encourage the growth and development of small and medium scale enterprises who more often than not are the employer of graduates of technical and TVE thereby creating jobs and reducing the rate of criminal activities in the society

\section{Acknowledgement}

The authors would like to thank all those who contributed to making this research successful. Also, we would like to thank to all the reviewers for their insightful comment. This work was sponsored by the Research Management Unit, Universiti of Teknologi Malaysia. 


\section{References}

[1] Action Aid Nigeria. . (2009). Country Strategy Paper 2009-2013: Fighting Poverty in the Midst of Plenty II. Action Aid Nigeria.

[2] Adebambo, K. A. (Ed.). (2007). Vocational and technical Education and training. Ibadan: Gabesther educational publishers.

[3] Adepegba, A. (2011, Saturday, 23 April). Police Arrest 51 Over Post Election Violence, The Punch.

[4] Agbolade, F. (2007). Resource Allocation and Utilization as Correlates of Students Academics Performance in Technical Colleges. Unpublished Manuscript. . Department of Educational Administration. University of Lagos Nigeria.

[5] Aiyedogbon, J. O., \& Ohwofasa, B. O. (2012). Poverty and youth Unemployment in Nigeria, 1987-2011. International Journal of Business and Social Science: 3(20), 269-279.

[6] Ajaegbu, O. O. (2012). Rising Youth Unemployment and Violent Crime in Nigeria. American Journal of Social Issues and Humanities: 2(5), 315-321.

[7] Akaninwor, K. G. I. (2001). Curriculum Issues in Technical and Vocational Programs for Sustainable PovertyAlleviation in Nigeria. In the proceedings of the conference of the NigeriaAssociation of Teachers of Technology (NATT), Lagos.

[8] Akerele, W. O. (2007). Management of Technical and Vocational Education in Nigeria: Challenges of the Country. Journal of Educational Administration and Planning: 3(1).

[9] Akintoye, I. R. (2008). Reducing Unemployment Through the Informal Sector: A Case Study of Nigeria. European Journal of Economics, Finance and Administrative Sciences: (11),97-106.

[10] Alanana, O. O. (2003). Youth Unemployment in Nigeria: Some Implications for the Third Millennium. Global. Journal of Social Sciences: 2(1), 21-26.

[11] Anyadike, N., Emeh, I. E. J., \& Ukah, F. O. (2012). EntrepreneurshipDevelopment and Employment Generation in Nigeria: Problems and Prospects. Journal of Education and General Studies: 1(4), 88-102.

[12] Apagu, V. V., \& Andural, S. I. (2007). Refocusing Nigerian Vocational Education for Relevance and Sustainable Development. Multidisciplinary Journal of Research Development: 9(1),1-8.

[13] Ashaye, M. A. (Ed.). (2007). Technical Teacher Education: Issues, Prospects and Challenges. In A.O.Ayoola \& B.P. Ehinmipare. (Eds). Technical and VocationalEducation: Assessment and Examination (Policy Issues). Ibadan: Gabesther educational publishers.

[14] Awakuna, P. O. (Ed.). (2006). Vocational and Technical Education: Issues and Prospects. Enugu: Dimension publishers.

[15] Awogbenle, A. C., \& Iwuamadi, K. C. (2010). Youth Unemployment: Entrepreneurship Development Programme as an Intervention Mechanism. African Journal of Business Managemen:, 4(6), 831-835.

[16] Ayinde, O. E. (2008). Empirical Analysis of Agricultural Growth and Unemployment in Nigeria. African Journal of Agricultural Research, 3(7), 465-468.

[17] Daily Trust. (2008). 80\% of Nigeria Youths Unemployed - FG, November 26., Daily Trust.

[18] Dike, V. E. (2009). Addressing Youth Unemployment and Poverty in Nigeria: A Call For Action Not Rhetorics. Journal of Sustainable Development in Africa: 11(3), 129-149.

[19] Ebong, J. M., \& Leigha, M. R. (2006). Graduate Unemployment in Nigeria. Concepts and Issues. African Journal of Education and Development Studies: 3(1), 103-111.

[20] Echebiri, R. N. (2005). Characteristics and Determinants of Urban Youth Unemployment in Umuahia, Nigeria: Implications for Rural Development and Alternative Labor Market Variables. A Paper presented at the ISSER/Cornell/World Bank conference on "Shared Growth in Africa", Accra, Ghana.

[21] Emeh, I. E., Nwanguma, E. O., \& Abaroh, J. J. (2012). Engaging Youth Employment in Nigeria with Youth Development and Empowerment Programs: Lagos State in Focus. Interdisciplinary Journal of Contemporary Research in Business: 4(5), 1125-1141.

[22] Epelle, A. (2010). Taming the Monster: Critical Issues in Arresting the Orgy of Youth Restiveness in the Niger Delta Region of Nigeria. In V. Ojakorotu and L.D. Gilbert (Eds.) Checkmating the Resurgence of OilViolence in the Niger Delta of Nigeria Retrieved December, $17^{\text {th }} 2012$, fromhttp://www.iags.org/Niger_Delta_book.pdf.

[23] Federal Republic of Nigeria. (2004). National Policy n Education. Lagos: Nigeria Education Research and Development Council Press

[24] Gilbert, 1. D. (2010). Youth Militancy, Amnesty and Security in the Niger Delta Region of Nigeria. In V. Ojakorotu and L.D. Gilbert (Eds.), Checkmating the Resurgence of Oil Violence in the Niger Delta of Nigeria.Retrieved December, 17th 2012, from http://www.iags.org/Niger_Delta_book.pdf

[25] Ibrahim, M. (2006). Empirical Survey of Children and Youth in Organized Violence in Nigeria Retrieved December, 20th, 2012, from http://www.coav.org.br/publique/media/Report\%20Nigeria.pdf

[26] Ibrahim, I. (2011). Nigeria, A Divided Country. Newswatch, 53(18), 19-22.

[27] Ideyi, N. (2010). The Root Cause Of Violence In Nigeria: The Niger Delta Crisis, A Reference Point Retrieved December, 18th 2012, from www.ajol.info/index.php/og/article/view/52331/40955

[28] Kalejaye, K. P. (Ed.). (2007). Vocational Education and National Development. In A.O. Ayoola \& B.P. Ehinmipare. (Eds.). Technical and Vocation Education: Assessment and Examination (Policy Issues). Ibadan: Gabesther educational publishers.

[29] Lartey, O. (2011, April, 20th). Four Burnt Alive, 45 Prison Inmates Released in Kaduna, The Punch.

[30] Maclean, R., \& Wilson, D. (Eds.). (2009). International Handbook of Education for the Changing World of Work: Bridging Academic and Vocational Learning. Dordrecht: Springer Science and Business Media.

[31] Moja, T. (Ed.). (2000). Nigeria Education Sector Analysis: An Analytical Synthesis of Performance and Main Issues. New York: New York University.

[32] National Bureau of Statistics. (NBS, 2009). Social Statistics in Nigeria. Abuja: The NBS Publication.

[33] National Bureau of Statistics. (2010). Statistical News: Labor Force Statistics No. $476 . \quad$ Abuja: The NBSPublication.

[34] National Bureau of Statistics, (2012). Labor Force Statistics. Retrieved from www.nigerianstat.gov.ng(USAEN, 2012).

[35] National Population Commission.(2006). National Population Census; Nigeria Population Figure. Abuja: National Population Census.

[36] National Population Commission.. (2009). National Population CommissionNigeria Demographic and Health Survey 2008. Abuja: National Population Commission Nigeria.

[37] Nwabuikwu, P. C. (2012). The Kamene Okonjo kidnap saga, The Sun. RetrievedDecember, 19thfrom sunnewsonline.com/.../newsreview-the-kamene-okonjo-kidnap

[38] Nwokomah, J. M. (2005). Strategic for Attainment of Functional Vocational and Technical Education in the 21st Century in Nigeria. Journal of Education in Developing Areas: 14, 53-61.

[39] Ojakorotu, V. (2010). Militants and Oil Violence in the Niger Delta of Nigeria: Any Implication for Security in Nigeria? In V. Ojakorotu and L.D. Gilbert (Eds.), Checkmating the Resurgence of Oil Violence in the NigerDelta of Nigeria. Retrieved December, $17^{\text {th }} 2012$, fromhttp://www.iags.org/Niger_Delta_book.pdf

[40] Okafor, E. E. (2007). Sociological Implications of Communal and Ethno-Religious Clashes in New Democratic Nigeria Journal of 
Tribes and Tribal: 5(1), 35-45.

[41] Okafor, E. E. (2011). Youth Unemployment and Implications for Stability of Democracy in Nigeria. Journal of Sustainable Development in Africa: (13), 358-372.

[42] Olatunji, S., \& Abioye, O., Wednesday, . (April $20^{\text {th }}, 2011$ ). Lecturers, Students, other killed in Kaduna, The Punch.

[43] Onyene, V. E., Olusanya, O., Salisu, R. A., \& Johnson, O. (2007). Production of Skill-Oriented Graduates for the Labor Market. A Paper Presented at the 1st International Conference of the Nigeria Association for Educational Administration and Planning Lagos, Nigeria.: NAEAP.

[44] Oyebade, S. A. (2003). Education and Unemployment of Youths in Nigeria: Causes, Impacts and Suggestions. Abuja: National Economic Empowerment Development Strategy (NEEDS).

[45] Patterson, N.; Okafor, O.\& Williams, D. (2006). Globalization and Employment Generation: Evaluating the Impact of Trade on Aggregate Employment in Nigeria's In Industrial Sector. Paper Presented at the NES Annual National Conference Nigeria.

[46] Puyate, S. T. (2001). Manpower Development Through Relevant Technology Education Curriculum for Sustainable Poverty Alleviation. In the Proceedings of the Conference of the Nigeria Association of Teachers of Technology (NATT). Lagos: Fembis international.

[47] Salami, C. G. E. (2011). Enterpreneurship and Youth Unemployment in Nigeria: The Missing Link. Global Journal of Management and Business Research, 11(5), Version 1.0.

[48] Shadare, O. A., \& Tunde, E. S. (2012). Graduate Unemployment in Nigeria: Causes, Effects and Remedies. British Journal of Arts and Social Sciences: 5(2), 142-154.

[49] United States Embassy in Nigeria, (2012). Nigerian Fact Sheet Retrieved December, 21st, 2012, from http://nigeria.usembassy.gov

[50] Utomi, P. (February $4^{\text {th } 2011 .) . ~ B e t r a y i n g ~ t h e ~ M i s s i o n ~ o f ~ t h e ~ G e n e r a t i o n ., ~ T h e ~ G u a r d i a n . ~}$ 